\section{Detailed mapping and lithogeochemistry of Neoarchean volcanic rocks: Beaulieu volcanic belt, Slave Craton, NWT}

\author{
Austin-Fafard, S.B., ${ }^{* 1}$, DeWolfe, Y.M.1,2, Partin \\ C. $A^{1}$, Knox, B. ${ }^{3}$
}

Neoarchean volcanic rocks of the Beaulieu River volcanic belt structurally overlie basement rocks of the Sleepy Dragon Complex (ca. $2.85 \mathrm{Ga}$ ), approximately $100 \mathrm{~km}$ east northeast of Yellowknife. The volcanic belt is comprised of complex lithofacies, including basalt, andesite, rhyolite, and associated volcaniclastic rocks, and hosts the Sunrise volcanogenic massive sulfide deposit. The absolute age of the volcanic strata is not known, nor is the stratigraphy well-defined; therefore, the Beaulieu River volcanic belt cannot be easily correlated to other greenstone belts within the Slave craton. The main objective of this study is to document the litho- and chemo-stratigraphy of the volcanic rocks, and particularly the rhyolite dome, located at the south end of Sunset Lake to reconstruct their volcanic and petrogenetic evolution, and determine their relationship to the volcanic strata that hosts the Sunrise VMS deposit, located $\sim 6 \mathrm{~km}$ to the north of the study area. Detailed mapping (1:2000) was completed over two field seasons (2018 and 2019) and shows that the volcanic rocks in the south Sunset Lake area comprise a complex stratigraphy consisting of basaltic, andesitic and rhyolitic lithofacies. This includes massive to pillow basalt and andesite, with lesser amounts of massive to in-situ brecciated, weakly quartz-plagioclase porphyritic rhyolite, heterolithic tuff to lapilli- tuff and felsic tuff to tuff breccia. The felsic clasts within the felsic volcaniclastic rocks are similar in composition to the coherent rhyolite. Units have a trace element geochemical signatures that vary from tholeiitic to calc-alkaline, arc-like rocks. Volumetrically, the volcanic strata in the south Sunset Lake area has a significant amount of volcaniclastic rocks, ranging from tuff to tuff breccia units. The volcaniclastic rocks are interpreted to have been deposited by a series of debris flows and eruption-fed density currents. The stratigraphy of the volcanic rocks in south Sunset Lake is very similar to that of the stratigraphy that hosts the Sunrise VMS deposit. Evidence of a vent proximal environment (e.g. rhyolite dome, peperite, syn-volcanic intrusions) and porous, volcanic debris accumulating on the seafloor highlight conditions favourable for volcanogenic massive sulfide-type mineralization in the south Sunset Lake area.

1 Department of Geological Sciences, College of Arts and Science, University of Saskatchewan, Saskatoon SK, Canada

2 Department of Earth and Environmental Sciences, Mount Royal University, Calgary AB, Canada

3 Northwest Territories Geological Survey, Yellowknife NT, Canada

* Correspondence: sba196@mail.usask.ca 
A detailed study of volcanic rocks: Beaulieu Belt, NWT (Austin-Fafard)

University of Saskatchewan Undergraduate Research Journal 